\title{
Now you see it, now you don't: Impact of temporary closures of a coal-fired power plant on air quality in the Columbia River Gorge National Scenic Area
}

\author{
D. A. Jaffe ${ }^{1}$ and D. R. Reidmiller ${ }^{1,2}$ \\ ${ }^{1}$ Department of Science and Technology, University of Washington-Bothell, USA \\ ${ }^{2}$ Department of Atmospheric Sciences, University of Washington-Seattle, USA \\ Received: 28 May 2009 - Published in Atmos. Chem. Phys. Discuss.: 30 June 2009 \\ Revised: 7 October 2009 - Accepted: 7 October 2009 - Published: 23 October 2009
}

\begin{abstract}
The goal of this study is to identify major point sources that contribute to elevated particulate matter in the Columbia River Gorge, USA and to quantify their contribution. To answer this question we analyzed 14 years of aerosol data spanning 1993-2006 from the IMPROVE site at Wishram, Washington $\left(45.66^{\circ} \mathrm{N}, 121.00^{\circ} \mathrm{W} ; 178 \mathrm{~m}\right.$ a.s.l.) in the Columbia River Gorge (CRG) National Scenic Area of the Pacific Northwest of the USA. Two types of analyses were conducted. First, we examined the transport for days with the highest fine mass $\left(\mathrm{PM}_{2.5}\right)$ concentrations using HYSPLIT backtrajectories. We found that the highest $\mathrm{PM}_{2.5}$ concentrations occurred during autumn and were associated with easterly flow, down the CRG. Such flow transports emissions from a large coal power plant in Boardman, Oregon and a large agricultural facility into the CRG. This transport was found on 20 out of the 50 worst $\mathrm{PM}_{2.5}$ days and resulted in an average daily concentration of $20.1 \mu \mathrm{g} / \mathrm{m}^{3}$, compared with an average of $18.8 \mu \mathrm{g} / \mathrm{m}^{3}$ for the 50 highest days and $5.9 \mu \mathrm{g} / \mathrm{m}^{3}$ for all days. These airmasses contain not only high $\mathrm{PM}_{2.5}$ concentrations, but also elevated levels of aerosol $\mathrm{NO}_{3}^{-}$. In the second analysis, we examined $\mathrm{PM}_{2.5}$ concentrations in the CRG during periods when the Boardman power plant was shut down due to repairs and compared these values with concentrations when the facility was operating at near full capacity. We also examined this relationship on the days when backtrajectories suggested the greatest influence from the power plant on air quality in the CRG. From this analysis, we found significantly higher $\mathrm{PM}_{2.5}$ concentrations when the power plant was operating at or near full capacity. We use these data to calculate that the contribution to $\mathrm{PM}_{2.5}$ mass in the CRG from the Boardman power plant was
\end{abstract}

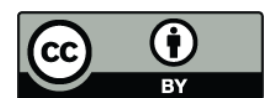

Correspondence to: D. A. Jaffe

(djaffe@u.washington.edu)
$0.90 \mu \mathrm{g} / \mathrm{m}^{3}$ averaged over the entire year, $3.94 \mu \mathrm{g} / \mathrm{m}^{3}$ if only the month of November is considered and $7.40 \mu \mathrm{g} / \mathrm{m}^{3}$ if only November days when the airflow is "down-gorge" (from east to west). This represents 14,46 and $56 \%$ of the $\mathrm{PM}_{2.5}$ mass in the CRG for the full year, November only and November days with "down-gorge" transport, respectively.

\section{Introduction}

The Columbia River is the largest river in the Pacific Northwest region of the USA extending from British Columbia, Canada to the Pacific Ocean. The Columbia River Gorge (CRG) is approximately $150 \mathrm{~km}$ long and forms part of the border between Oregon and Washington State. For most of this distance the river is $1-2 \mathrm{~km}$ wide in the CRG. Figure 1 maps the region and some of the major features in the area. The Columbia River Gorge National Scenic Area (CRGNSA) was established in 1986 by an act of the US Congress "To protect and enhance the scenic, natural, cultural and recreational resources of the Columbia River Gorge," (see Columbia River Gorge Commission website at http://www.gorgecommission.org). Due to air quality concerns in the CRGNSA, the amended Gorge management plan crafted in 2000 directed the states, US Forest Service and the Southwest (Washington) Clean Air Agency to "... identify all sources, both inside and outside the Scenic Area that significantly contribute to air pollution". Since then a number of studies have been presented and/or published on this issue (Green et al., 2006; Fenn et al., 2007; Pitchford et al., 2008).

Sources of pollution in or near the CRG include automobile traffic, diesel powered trains, marine vessels, agriculture and emissions from the Portland Metropolitan Area

Published by Copernicus Publications on behalf of the European Geosciences Union. 


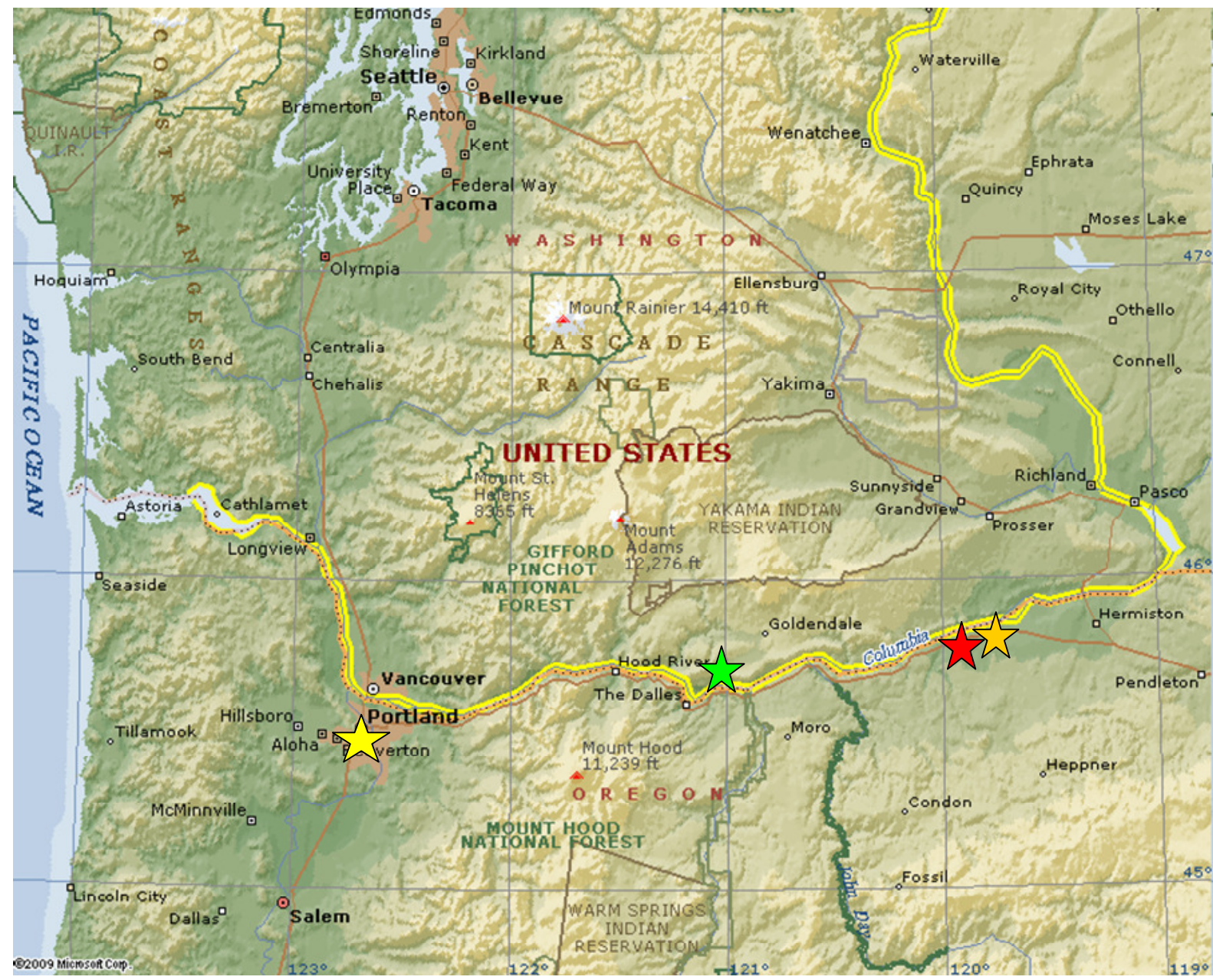

Fig. 1. Map of the Columbia River Gorge showing the locations of: the city of Portland (yellow star), Wishram IMPROVE site (green star), Boardman power plant (orange star); Threemile Canyon dairy farm (red star). The Columbia River is highlighted in yellow. Interstate-84 parallels the Columbia River from Portland through Boardman.

(PMA) at the western end of the CRG, and one large industrial facility and a large dairy farm on the eastern end of the CRG. Emissions contributing to $\mathrm{PM}_{2.5}$ from the PMA (pop. $\sim 576000$ ) are dominated by mobile sources (Oregon Dept. of Environmental Quality, http://www.deq.state. or.us/aq/toxics/docs/pataei.pdf). Interstate- 84 traverses the Washington/Oregon border (i.e., along the CRG) from Portland eastward for $\sim 200 \mathrm{~km}$ where it heads to the southeast. Annual average daily traffic is $10000-20000$ vehicles/day outside the PMA (http://www.interstate-guide.com/ i-084aadt.html) with a mix of diesel trailers and personal automobiles. The two major industrial facilities are the Threemile Canyon dairy farm and the Portland General Electric coal-fired power plant both of which are located in Boardman, Oregon (see Fig. 1). The dairy farm has $\sim 50000$ dairy cows and replacement heifers on-site at most times. Despite the fact that the facility utilizes closed-loop methods to handle the wastes and re-uses as much of it as possible in a co- located crop-growing operation, we expect the facility has significant emissions of $\mathrm{NH}_{3}$. A recent re-analysis suggests $\mathrm{NH}_{3}$ emissions of at least $55 \mathrm{~kg} / \mathrm{head} /$ year (B. Lamb, personal communication, 2008).

The 540 MW power plant in Boardman uses low sulfur coal from the Powder River Basin in Montana and Wyoming. An electrostatic precipitator removes $99.5 \%$ of the fly ash and the plant uses low $\mathrm{NO}_{\mathrm{x}}$ burners. The plant, which started operations in 1980, has no other gas or particulate emission controls. According to data from the EPA AirData website (http://www.epa.gov/air/data/) emissions for 2001 were 16000 and 10000 metric tons/year for $\mathrm{SO}_{2}$ and $\mathrm{NO}_{\mathrm{x}}$, respectively. This makes it the largest point source for these two pollutants in the state of Oregon.

Once released, $\mathrm{NO}_{\mathrm{x}}$ and $\mathrm{SO}_{2}$ will quickly oxidize in the plume to $\mathrm{HNO}_{3}$ and aerosol $\mathrm{SO}_{4}^{2-}$ (Eatough et al., 1981; Hewitt, 2001). Since the area of the dairy farm essentially abuts the power plant, we expect significant interaction between 
the power plant and dairy farm emissions. In the presence of $\mathrm{NH}_{3}, \mathrm{HNO}_{3}$ will likely form $\mathrm{NH}_{4} \mathrm{NO}_{3}$ aerosol and $\mathrm{SO}_{4}^{2-}$ will form $\left(\mathrm{NH}_{4}\right)_{2} \mathrm{SO}_{4}$ on a timescale dependent upon trace gas concentrations, relative humidity, wind speed and other meteorological factors (Seinfeld and Pandis, 2006). The overall result is that we expect a significant fraction of the gaseous power plant emissions to convert to PM in a relatively short time.

To date, the most comprehensive air quality study for the CRG was done by an interagency group to assess and develop recommendations for the CRG. While some measurements were conducted, the source attribution was largely based on an Eulerian air quality model (Green et al., 2006; Pitchford et al., 2008). The results from these studies found air quality in the CRG tended to be worst during autumn and was associated with easterly or "downstream" transport through the CRG. They also found that the sources of aerosols in the CRG were many and that no one source dominated. However, evaluation of the chemical transport model revealed very poor agreement with the observed PM concentrations, particularly at high $\mathrm{PM}_{2.5}$ mass concentrations, when air quality is of the greatest concern (see Fig. 5-1 of Pitchford et al., 2008). This is not surprising given the challenges of modeling in a region with complex topography. The CRG is a long, narrow $(1-2 \mathrm{~km})$ and curved river valley, with hills rising 500-1300 $\mathrm{m}$ above the river. Sharp and Mass (2004) found that in order to model airflow in the CRG accurately, the horizontal grid spacing needs to be $500 \mathrm{~m}$ or less. The Eulerian model used in the Green et al. (2006) and Pitchford et al. (2008) studies had a resolution of $4 \mathrm{~km} \times 4 \mathrm{~km}$, which was nested within a $12 \mathrm{~km}$ grid covering the Pacific Northwest, all of which was nested within a $36 \mathrm{~km}$ grid covering the continental USA. Boundary conditions for the $36 \mathrm{~km}$ continental USA domain were provided by the GEOS-Chem global chemical transport model.

Due to the challenges of air quality modeling in regions of complex terrain, we sought to focus on the available observations to better understand the contribution from specific sources. In particular, we can use operational data from the Boardman power plant to examine changes in air quality during plant shutdowns. Previous studies have used similar methods to investigate the contribution from large industrial facilities on local and regional air quality by comparing pollutant levels during normal operations to those observed during temporary or permanent closures (Eldred et al., 1983; Vong et al., 1988; Romo-Kroger et al., 1994). These studies, from a variety of locations, used similar methods to quantify the impact of a specific facility on air quality including precipitation chemistry (Vong et al., 1988), heavy metal concentrations (Romo-Kroger et al., 1994) and aerosol $\mathrm{SO}_{4}^{2-}$ concentrations (Eldred et al., 1983).

The general goals of our study are to use the 14 year record of aerosol observations in the CRG from the IMPROVE network and plant closure data to quantify its impacts. Specific questions to address are:
1. What can backtrajectories tell us about the transport and sources for PM on the worst air quality days in the CRG?

2. Can we use emissions data from the Boardman plant to quantify its contribution to $\mathrm{PM}_{2.5}$ concentrations based on when the plant was shut down?

3. How do these results compare to the previous work of Green et al. (2006) and Pitchford et al. (2008) which used an Eulerian model to attribute sources of PM in the CRG?

\section{Data and methods}

The Interagency Monitoring of Protected Visual Environments (IMPROVE) network began making PM measurements in 1988 at nearly 200 sites across the USA (Malm et al., 1994; http://vista.cira.colostate.edu/improve/). Samples are collected for $24 \mathrm{~h}$, approximately every 3 days and analyzed for fine mass (aerodynamic diameter $<2.5 \mu \mathrm{m}$ ) and coarse mass $(2.5-10 \mu \mathrm{m})$, as well as an array of chemical species on the fine aerosol including $\mathrm{NO}_{3}^{-}, \mathrm{SO}_{4}^{2-}$, elemental and organic carbon, and many other trace species. For our analysis we used data from the IMPROVE site located in Wishram, Washington (CORI1) which is located at $45.66^{\circ} \mathrm{N}$, $121.0^{\circ} \mathrm{W}$ and $178 \mathrm{~m}$ a.s.l. This is the only IMPROVE site located in the central CRG with a long-term record. The site has been in operation since 1993. Our analysis covers the period of 1993-2006. Data were obtained from the aforementioned IMPROVE website.

Airmass backtrajectories were calculated using the NOAA-HYSPLIT model (Draxler and Rolph 2003), with arrival heights of 0,100 and $500 \mathrm{~m}$ above ground level (a.g.l.). Vertical motions were calculated using the modeled vertical velocity. For each $24 \mathrm{~h}$ sample period, trajectories were calculated at $2 \mathrm{~h}$ intervals, leading to a total of 13 backtrajectories for each sample and each arrival height. For each date a total of 39 backtrajectories were calculated ( 3 arrival heights $\times 13$ per height). Backtrajectories were calculated using the highest resolution meteorological data available. For 2004-2006 we used the EDAS database with a $40 \mathrm{~km}$ grid resolution. For 1997-2003, we used the EDAS database, with an $80 \mathrm{~km}$ grid resolution. For 1993-1996, we used the NCEP reanalysis data, which has a much more coarse $2.5^{\circ} \times 2.5^{\circ}$ grid resolution. Some exceptions to this were made when higher resolution data was not available for a particular date. It is important to note that while the backtrajectories are based on relatively coarse meteorological data, we are only using them to identify general patterns of airflow. The actual source attribution is based on the IMPROVE observations (see below).

Emissions data for the Portland General Electric power plant in Boardman, Oregon were provided by Mark Fisher from the Oregon Department of Environmental Quality 
Table 1. Monthly distribution of the 50 highest $\mathrm{PM}_{2.5}$ days from 1993-2006 at the Wishram, Washington (USA) IMPROVE site.

\begin{tabular}{cccccccccccc}
\hline Jan & Feb & Mar & Apr & May & Jun & Jul & Aug & Sep & Oct & Nov & Dec \\
\hline 3 & 3 & 0 & 1 & 0 & 1 & 5 & 5 & 3 & 5 & 20 & 4 \\
\hline
\end{tabular}

(ODEQ). The monthly $\mathrm{NO}_{\mathrm{x}}$ and $\mathrm{SO}_{2}$ emissions were collected using measurements from continuous emission monitors and reported annually to ODEQ on Form F1106 for the years 1992-2006.

To answer the four questions posed at the end of the previous section, we employ the following methodology:

a) We used the Wishram IMPROVE aerosol data to identify the 50 days with the highest $\mathrm{PM}_{2.5}$ mass (worst air quality) from 1993-2006;

b) For these days, we calculated backtrajectories (initiated every $2 \mathrm{~h}$ at 3 starting altitudes) to understand the transport history of the airmass sampled at Wishram;

c) Using these trajectories, we classified the 50 days with highest $\mathrm{PM}_{2.5}$ mass according to the most likely pollution source region;

d) Based on the backtrajectory classifications, we examined the aerosol chemistry data to determine if there is a significant difference in aerosol composition for air transported over the two distinct regions (PMA vs. east CRG)

e) Using the emissions data from the Boardman power plant we quantified its contribution to $\mathrm{PM}_{2.5}$ concentrations in the CRG when the plant was shut down completely (November 2005) or for other times when the plant was operating at very low capacity.

\section{Results}

\subsection{Aerosol climatology for Wishram IMPROVE site}

As illustrated in Fig. 1, the Wishram IMPROVE site is located on the shore of the Columbia River about midway between the city of Portland and the Boardman power plant $\left(45.66^{\circ} \mathrm{N}, 121.00^{\circ} \mathrm{W} ; 178 \mathrm{~m}\right.$ a.s.l.). IMPROVE aerosol observations from the site began in June 1993. The data record has 1372 days with valid $\mathrm{PM}_{2.5}$ data. The mean $\mathrm{PM}_{2.5}$ mass concentration for all days is $5.8 \pm 3.9 \mu \mathrm{g} / \mathrm{m}^{3}($ mean $\pm 1 \sigma)$. The mean $\mathrm{PM}_{2.5}$ mass concentration for the 50 highest days is $18.8 \pm 4.4 \mu \mathrm{g} / \mathrm{m}^{3}$. The highest daily mean $\mathrm{PM}_{2.5}$ mass concentration was observed on 7 November 2002 at $34.7 \mu \mathrm{g} / \mathrm{m}^{3}$. For context, the USA National Ambient Air Quality Standard (NAAQS) for the 24-h mean $\mathrm{PM}_{2.5}$ mass concentration is $35 \mu \mathrm{g} / \mathrm{m}^{3}$; the annual mean NAAQS threshold is $15.0 \mu \mathrm{g} / \mathrm{m}^{3}$.
Table 1 shows the monthly distribution for the 50 days with highest $\mathrm{PM}_{2.5}$ concentrations. The frequency of high $\mathrm{PM}_{2.5}$ days spikes in November, with 20 of the 50 highest $\mathrm{PM}_{2.5}$ days $(40 \%)$ occurring in that month.

\subsection{Backtrajectory analysis}

While backtrajectories do not provide an absolute identification of sources, they may indicate the most likely source. Backtrajectories are good at discriminating between two possible sources that are in different directions. An analysis of backtrajectories does not provide a quantitative measure of one source's contributions when multiple sources are adjacent. Uncertainty in the spatial resolution of the meteorological inputs used to calculate backtrajectories can also complicate their interpretation. In general, backtrajectories have a horizontal uncertainty of approximately $1 / 3-1 / 2$ of the distance traveled. In addition, on certain days, backtrajectories can yield a confusing or ambiguous result. Furthermore, backtrajectories cannot provide quantitative information on source attribution to the overall pollution loading in the CRG. However, despite these limitations, backtrajectories can add important corroborating information to aerosol and chemical observations.

For each sample date, the airmass was classified with respect to its most likely source region based on the 39 trajectories (initialized every $2 \mathrm{~h}$ at 3 altitudes). If all backtrajectories arriving at Wishram showed consistent transport, then we have the greatest confidence in our assignment of a source region. Backtrajectories were classified into one of five categories: 1 = West Gorge; $2=$ West Gorge-likely, but some ambiguity; 3 = no obvious source region; 4 =East Gorge likely, but some ambiguity; $5=$ East Gorge. West Gorge refers to cases where the majority of trajectories originated or crossed through the PMA (west of $122^{\circ} \mathrm{W}$ ) and East Gorge refers to cases where the majority of trajectories originated east of $120^{\circ} \mathrm{W}$. Categories 1 and 5 were assigned in cases when at least $90 \%$ of the 39 trajectories had transport pathways within $30^{\circ}$ of $270^{\circ}$ and $80^{\circ}$ respectively, for the $24 \mathrm{~h}$ trajectory time. These directions $\left(270^{\circ}\right.$ and $\left.80^{\circ}\right)$ are the primary orientation of the CRG within $100 \mathrm{~km}$ of the Wishram site.

As an example, Fig. 2 shows backtrajectories for the IMPROVE sample taken on 11 November 2004. This date had a $\mathrm{PM}_{2.5}$ mass concentration of $24.6 \mu \mathrm{g} / \mathrm{m}^{3}$, making it the 6th highest $\mathrm{PM}_{2.5}$ days in the 14 years of IMPROVE samples. The 13 trajectories shown (for the initialization altitude of $0 \mathrm{ma}$ a.g.l.) indicate that pollution sources in the 


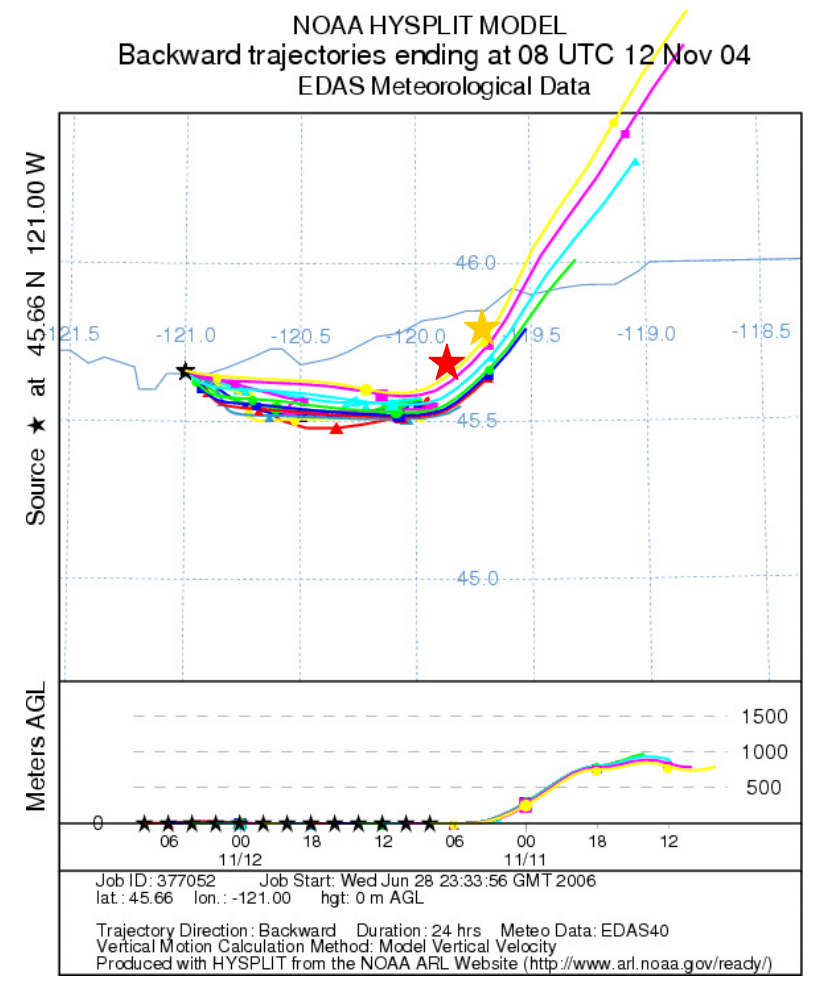

Fig. 2. HYSPLIT one day backtrajectories arriving at Wishram on 11 November 2004 at two hours intervals. At the bottom of figure, the stars show the arrival time for each back-trajectory in UTC. The trajectories indicate air flow from the east. The orange star indicates the location of the Boardman power plant and the red star denotes the location of the Threemile Canyon dairy farm.

eastern end of the CRG were most likely responsible for the high $\mathrm{PM}_{2.5}$. Green et al. (2006) reported high levels of PM between 7-12 November 2004 and also attributed this to sources in the east end of the CRG. To quote from Green et al. (2006), "As levels of the aerosol scattering coefficient decreased from east to west, this suggests that most impact was due to sources east of the Gorge, rather than within the Gorge". Thus, our backtrajectory analysis is consistent with the results from the Green et al. (2006) study. Based on the monthly analysis shown in Table 1, November is the most common month to see high levels of $\mathrm{PM}_{2.5}$ at Wishram. This date, 11 November 2004, was classified as backtrajectory category 5 (East Gorge).

Each of the 50 days with the highest $\mathrm{PM}_{2.5}$ mass were classified in this way. The results are shown in Table 2, along with the associated mean $\mathrm{PM}_{2.5}$ mass concentration for each backtrajectory category. Based on this analysis, transport from the east end of the CRG is responsible for at least 30\% of the worst air quality days. Adding in backtrajectory category 4 (East Gorge possible, but not certain), indicates that about $40 \%$ of the days with high $\mathrm{PM}_{2.5}$ concentrations, are most likely due to sources on the east end of the CRG. In
Table 2. Daily mean concentrations and backtrajectory category for the 50 highest $\mathrm{PM}_{2.5}$ days.

\begin{tabular}{lcc}
\hline Backtrajectory category & Number & Mean $\mathrm{PM}_{2.5}\left(\mu \mathrm{g} / \mathrm{m}^{3}\right)$ \\
\hline 1 - West Gorge & 4 & 16.5 \\
2 - West Gorge possible & 4 & 17.7 \\
3 - Unassigned or other & 22 & 18.2 \\
4 - East Gorge possible & 4 & 20.1 \\
5 - East Gorge & 16 & 20.1 \\
All others & 1322 & 5.4 \\
\hline
\end{tabular}

Table 3. Percent composition of Wishram $\mathrm{PM}_{2.5}$ aerosol by backtrajectory classification. Categories $1-5$ refer to the trajectory classifications for the 50 days with the highest $\mathrm{PM}_{2.5}$ concentrations.

\begin{tabular}{lcccccc}
\hline \multirow{2}{*}{ Aerosol Component } & \multicolumn{6}{c}{ Backtrajectory Category } \\
\cline { 2 - 7 } & 1 & 2 & 3 & 4 & 5 & All others \\
$n=4$ & $n=4$ & $n=22$ & $n=4$ & $n=16$ & $n=1322$ \\
\hline $\mathrm{NO}_{3}^{-}$ & 1.5 & 6.1 & 18.3 & 16.9 & 32.8 & 11.4 \\
$\mathrm{SO}_{4}^{2-}$ & 5.8 & 8.0 & 13.9 & 9.8 & 8.8 & 16.5 \\
Organic & 13.2 & 39.7 & 25.8 & 32.9 & 25.8 & 27.2 \\
Soil & 69.0 & 9.7 & 10.9 & 9.0 & 7.6 & 15.2 \\
Other & 10.5 & 36.6 & 31.1 & 31.4 & 25.1 & 29.6 \\
\hline
\end{tabular}

addition, the mean $\mathrm{PM}_{2.5}$ mass concentrations for backtrajectory categories 4 and 5 (east CRG) exhibit higher values than those from the other backtrajectory categories.

Because the HYSPLIT backtrajectories were calculated with coarse meteorological data, we also used local winds measured at the Dalles, Oregon municipal airport, $16 \mathrm{~km}$ west of Wishram, to corroborate the trajectory classifications. For this we calculated daily average $(24 \mathrm{~h})$ vector wind based on the hourly wind speed and direction. Of the 16 days, with backtrajectory category 5 (East Gorge highly probable), 13 had sufficient local wind data to make this comparison. Of these 13 days, 10 had daily average vector wind directions between $60-160^{\circ}$ consistent with easterly flow and our backtrajectory classification.

\subsection{Aerosol composition analysis}

Since the IMPROVE samples undergo a fairly complete chemical characterization, we can use this information to examine the chemical characteristics by transport type. Table 3 shows the chemical composition (\% of total mass) by backtrajectory category. From this analysis, two distinguishing features are revealed: (a) very high $\mathrm{NO}_{3}^{-}$concentrations in the East Gorge samples and (b) very high soil composition in the West Gorge samples.

Atmospheric $\mathrm{NO}_{3}^{-}$can come from two sources: (1) emissions of $\mathrm{NO}_{\mathrm{x}}$, which are subsequently oxidized to $\mathrm{HNO}_{3}$ 
or aerosol $\mathrm{NO}_{3}^{-}$, and (2) emissions of $\mathrm{NH}_{3}$, some fraction of which are oxidized to $\mathrm{NO}_{\mathrm{x}}$ and subsequently to $\mathrm{NO}_{3}^{-}$. Most likely, the $\mathrm{NO}_{\mathrm{x}}$ source is dominant in the region of study, but a significant contribution from $\mathrm{NH}_{3}$ cannot be ruled out. Thus, the high $\mathrm{NO}_{3}^{-}$component from the east $\mathrm{CRG}$ sources is consistent with our understanding of sources in the region. The Boardman power plant emits approximately 10000 metric tons/year of $\mathrm{NO}_{\mathrm{x}}$, which is 6-7\% of all $\mathrm{NO}_{\mathrm{x}}$ emissions in the State of Oregon. Also, the Oregon counties on the east end of the CRG (Morrow, Umatilla, Union, Grant and Baker) emit nearly 9000 metric tons/year of $\mathrm{NH}_{3}$ (2001 data), which is $\sim 20 \%$ of the Oregon total. Umatilla County is one of the most concentrated regions for $\mathrm{NH}_{3}$ emissions, accounting for nearly $10 \%$ of the statewide total. These numbers may in fact be low due to recent growth in the dairy industry in this region. While the IMPROVE data do not provide reliable $\mathrm{NH}_{3}$ air concentrations, it is likely that significant concentrations of gaseous $\mathrm{NH}_{3}$ and $\mathrm{NH}_{4}^{+}$compounds also occur under easterly winds in the CRG. The high $\mathrm{NO}_{3}^{-}$concentrations in these airmasses is corroborated by the results of Fenn et al. (2007) who find large amounts of nitrogen-loving lichens in the CRG, compared to other similar regions of the Pacific Northwest.

The high soil component for the west CRG samples (backtrajectory category 1) is somewhat surprising, however this category includes only 4 samples. Two of the four cases (16 July 2002 and 17 July 2004) had unusually high soil concentrations: $77 \%$ and $75 \%$ of the total fine aerosol mass on these two dates, respectively. One possible explanation is that these samples were significantly influenced by forest fire emissions, which can contain substantial soil dust. Using the Navy's NAAPS aerosol model and MODIS satellite detected fire data (see http://www.nrlmry.navy.mil/aerosol/ index_shortcuts.html), it appears that the CRG was likely influenced by forest fire smoke during these two periods. A significant amount of soil dust can get lofted with the smoke leading to elevated dust levels in forest fire plumes.

It is surprising that there are not more days with high $\mathrm{PM}_{2.5}$ mass concentrations coming from the PMA, since westerly winds are common in the CRG. Although we have not conducted a detailed analysis to explain this result, it is quite possible that the relatively lower concentrations seen at Wishram during westerly transport is a result of strong dilution of the PMA airmasses, differing topography on the west end of the CRG and the higher prevalence of clouds in the west CRG contributing to enhanced deposition before the airmass reaches Wishram.

\subsection{Effect of Boardman power plant closures on $\mathbf{P M}_{2.5}$ in the CRG}

$\mathrm{NO}_{\mathrm{x}}$ emissions for the Boardman power plant are typically $800-1100$ metric tons per month when the plant is operating at, or near, full capacity. However, from 1992-2006, there have been several periods with extended shutdowns that re-

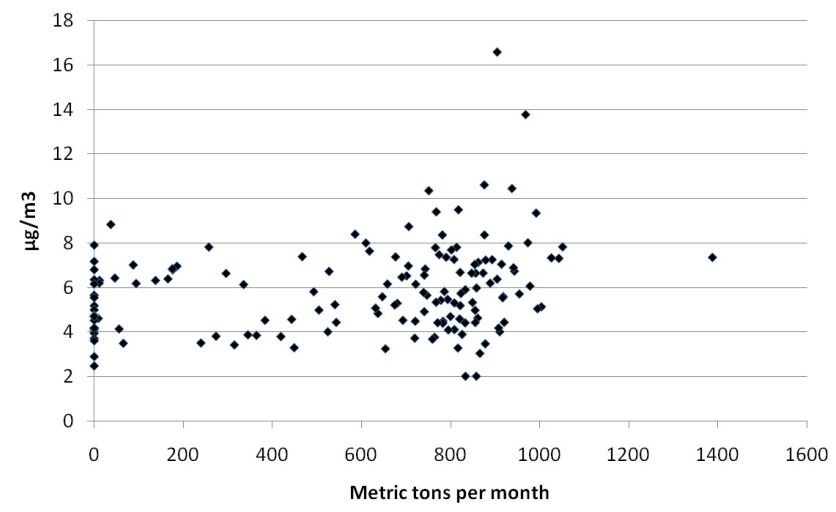

Fig. 3. Monthly mean fine mass concentration $\left(\mathrm{PM}_{2.5}\right)$ measured at Wishram vs PGE Boardman $\mathrm{NO}_{\mathrm{x}}$ emissions (metric tons/month) for the period 1993-2006.

sulted in significantly lower $\mathrm{NO}_{\mathrm{x}}$ emissions. If no coal is burned, then no $\mathrm{NO}_{\mathrm{x}}$ is generated (or emitted). These shutdowns have occurred for a variety of reasons, both scheduled and unscheduled. Of the 163 months for which we have Boardman power plant emissions data, 34 months have $\mathrm{NO}_{\mathrm{x}}$ emissions of less than 100 metric tons/month. It is important to note that we use the Boardman power plant $\mathrm{NO}_{\mathrm{x}}$ emissions as a surrogate for all plant emissions (i.e., if $\mathrm{NO}_{\mathrm{x}}$ emissions are essentially zero, then all other emissions will be near zero).

We examined the full Wishram IMPROVE dataset to see if an improvement in air quality during months when the Boardman power plant had zero (or insignificant) $\mathrm{NO}_{\mathrm{x}}$ emissions was observed. Note, there are 163 months with power plant emissions data (June 1993-December 2006), but only 152 months have corresponding $\mathrm{PM}_{2.5}$ data from the Wishram site. Figure 3 shows the monthly average $\mathrm{PM}_{2.5}$ mass concentration measured at Wishram vs. the Boardman power plant $\mathrm{NO}_{\mathrm{x}}$ emissions. A significant linear relationship is not seen, which is not surprising given the large seasonal and daily variations in meteorology and transport. However, upon closer examination, Fig. 3 shows that only when the power plant $\mathrm{NO}_{\mathrm{x}}$ emissions are high, do we get high $\mathrm{PM}_{2.5}$ mass concentrations in the CRG. Similarly, it is also true that $\mathrm{PM}_{2.5}$ mass concentrations are only high $\left(>10 \mu \mathrm{g} / \mathrm{m}^{3}\right)$ when power plant $\mathrm{NO}_{\mathrm{x}}$ emissions are greater than $\sim 800$ metric tons/month. When the data is segregated to compare months with low emissions vs. months with high (or normal) emissions, there is a significant difference in $\mathrm{PM}_{2.5}$ mass concentration observed in the CRG. Using a ttest to compare months with $\mathrm{NO}_{\mathrm{x}}$ emissions above and below 100 metric tons, the difference in $\mathrm{PM}_{2.5}$ mass concentration is $0.87 \mu \mathrm{g} / \mathrm{m}^{3}$ and is statistically significant with a confidence of $95 \%$ or greater. Segregating the data with slightly different criteria (e.g., 200 tons/month or 300 tons/month) has no impact on this conclusion. Table 4 summarizes this result. 
Table 4. Comparison of $\mathrm{PM}_{2.5}$ mass data for months with power plant $\mathrm{NO}_{\mathrm{x}}$ emissions greater than, and less than, 100 metric tons. The difference $\left(0.87 \mu \mathrm{g} / \mathrm{m}^{3}\right)$ is statistically significant at a confidence of $95 \%$ or better.

\begin{tabular}{lll}
\hline & $\begin{array}{l}\text { Months with } \\
\text { emissions }>100 \text { tons }\end{array}$ & $\begin{array}{l}\text { Months with } \\
\text { emissions }<100 \text { tons }\end{array}$ \\
\hline $\begin{array}{l}\text { Number of months } \\
\mathrm{PM}_{2.5} \text { mass, mean } \pm 1 \sigma\end{array}$ & $\begin{array}{l}121 \\
\left(\mu \mathrm{g} / \mathrm{m}^{3}\right)\end{array}$ & 31 \\
\hline
\end{tabular}

Results presented in Sect. 3.1 show that November is the worst month in terms of high $\mathrm{PM}_{2.5}$ days in the CRG. Therefore, we expect to identify an even larger influence on air quality in the CRG from the Boardman power plant during autumn, particularly in November. Of the months with very low power plant $\mathrm{NO}_{\mathrm{x}}$ emissions, one period occurred in November 2005, when the plant suffered an extended shutdown (November 2005-June 2006) due to a turbine failure. From an air quality point of view, the cleanest November on record was in 2005, with an average $\mathrm{PM}_{2.5}$ mass concentration of $4.61 \mu \mathrm{g} / \mathrm{m}^{3}$. Comparing the measured daily $\mathrm{PM}_{2.5}$ mass concentrations for November $2005(n=10)$ with all other November data $(n=108)$ reveals a significantly decreased aerosol loading in the CRG $8.55 \pm 1.27 \mu \mathrm{g} / \mathrm{m}^{3}$ vs. $4.61 \pm 2.32 \mu \mathrm{g} / \mathrm{m}^{3}$ (mean $\pm 95 \%$ confidence interval). Figure 4 depicts this difference (blue bars). A t-test confirms that the difference $\left(3.94 \mu \mathrm{g} / \mathrm{m}^{3}\right)$ is statistically significant with a confidence greater than $95 \%$.

We further segregate the data by recalling that the influence from sources in the eastern end of the CRG was strongest when airmass backtrajectories indicated strong transport from the east end of the CRG. Figure 4 also compares $\mathrm{PM}_{2.5}$ mass concentration from November 2005 with all other November data, but in both cases, only days with airmass transport from the eastern CRG are included (red bars in Fig. 4; backtrajectory category 5). While this significantly reduces the number of data points ( $n=23$ for all November, and $n=5$ for November 2005), it isolates the strong influence from the Boardman power plant emissions. For dates with transport from the eastern CRG, the average $\mathrm{PM}_{2.5}$ mass concentration in November 2005 is $5.94 \pm 1.32 \mu \mathrm{g} / \mathrm{m}^{3}$ vs. $13.34 \pm 3.40 \mu \mathrm{g} / \mathrm{m}^{3}$ for all other November data with similar transport patterns (mean $\pm 95 \%$ confidence interval). A t-test confirms that the difference $\left(7.40 \mu \mathrm{g} / \mathrm{m}^{3}\right)$ is statistically significant at a confidence of greater than $95 \%$.

Together, these three analyses present a consistent picture of the influence from the Boardman power plant on $\mathrm{PM}_{2.5}$ air quality in the CRG. Using the analysis for all months, we find that the power plant influence on $\mathrm{PM}_{2.5}$ in the CRG is, on average, $0.87 \mathrm{~m} \mu \mathrm{g} / \mathrm{m}^{3}$. Comparing only November data, we find that the influence is significantly greater at $3.94 \mu \mathrm{g} / \mathrm{m}^{3}$.

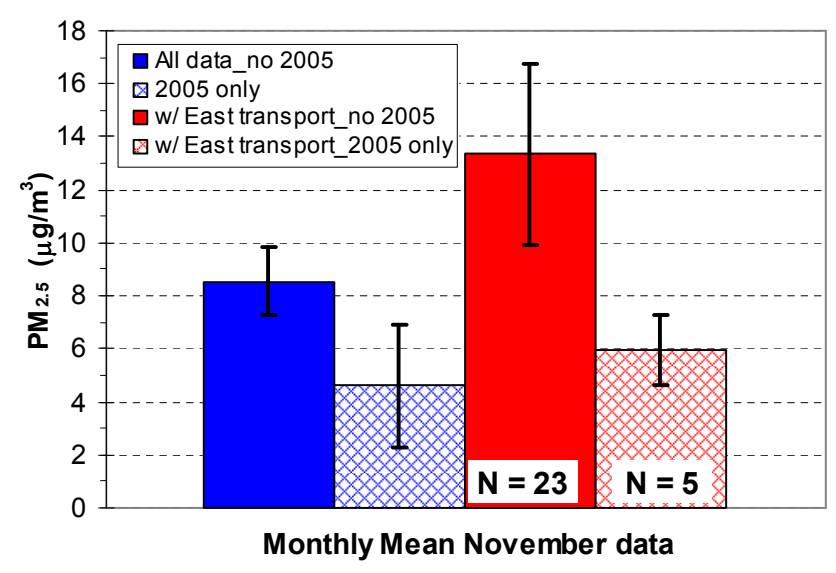

Fig. 4. Comparison of IMPROVE data from Wishram for all November data except 2005 (solid bars) with November 2005 data (cross-hatched). The comparison on the left (blue) is for all November data. The comparison on the right only includes those days with trajectories coming from the east end of the CRG. More detailed data are shown in Table 5, including 95\% confidence intervals on each value.

Comparing only November data for days with transport from the eastern CRG, we find the influence is greatest at $7.40 \mu \mathrm{g} / \mathrm{m}^{3}$. Table 5 summarizes the results and also derives the $\%$ contribution at Wishram due to emissions from the Boardman power plant.

\section{Comparison to other studies}

The Columbia Gorge management plan directed several federal agencies, the states and several local agencies to cooperate on a detailed air quality study in the CRG. This study took place between 2000-2007 and the results are presented in Pitchford et al. (2008). Augmented measurements were collected during 2004. However, the primary conclusions on source attribution were derived from analysis of a regional air quality model. In this section we compare our results to those from this study (Columbia River Gorge Air Quality Study, Science Summary Report, Pitchford et al., 2008). As part of the observations and modeling that was conducted by Pitchford et al. (2008), attention focused on one air pollution episode, which occurred between 8-14 November 2004. Pitchford et al. (2008), as well as our results reported herein, found that emissions in the east end of the CRG were largely responsible for this episode. Therefore, it is reasonable to compare the results from this November episode with our results for November when backtrajectories suggest the airmass traveled from the eastern CRG. Table 5 suggests that the Boardman power plant is responsible for approximately $55 \%$ of the $\mathrm{PM}_{2.5}$ mass during this episode. This is in contrast to Pitchford et al. (2008) who state that Electric Generation Units (EGUs) on the east end of the CRG (the Boardman 
Table 5. Summary of $\mathrm{PM}_{2.5}$ mass concentrations at the Wishram IMPROVE site with and without the influence from Boardman power plant emissions. The $95 \% \mathrm{CI}$ is shown in parantheses.

\begin{tabular}{lcccc}
\hline & $\begin{array}{c}\text { With power plant influence } \\
\left(\mu \mathrm{g} / \mathrm{m}^{3}\right)\end{array}$ & $\begin{array}{c}\text { Without power plant influence } \\
\left(\mu \mathrm{g} / \mathrm{m}^{3}\right)\end{array}$ & $\begin{array}{c}\text { Difference } \\
\left(\mu \mathrm{g} / \mathrm{m}^{3}\right)\end{array}$ & $\begin{array}{c}\text { PM } \\
2.5\end{array}$ \\
\hline All months $^{\mathrm{a}}$ & $6.06(2.11)$ & $5.19(1.49)$ & 0.87 & 14.3 \\
All November data $^{\mathrm{b}}$ & $8.55(1.27)$ & $4.61(2.32)$ & 3.94 & 46.1 \\
All November data w/ & $13.34(3.40)$ & $5.94(1.32)$ & 7.40 & 55.5 \\
trajectories from East $\mathrm{CRG}^{\mathrm{c}}$ & & & & \\
\hline
\end{tabular}

a This row compares months where Boardman power plant emissions are less than 100 tons vs. all other months.

b This row compares the November 2005 data (power plant shutdown) with all other November data.

c This row compares November 2005 data with east CRG backtrajectories with all other November data with east CRG backtrajectories.

power plant) were responsible for $32 \%$ of the $\mathrm{PM}_{2.5}$ mass at Wishram, a significant difference from our results.

In addition, our analysis indicates that for the November episodes with easterly transport, the Boardman power plant contribution is $7.40 \mu \mathrm{g} / \mathrm{m}^{3}$ at the Wishram IMPROVE site, whereas Pitchford et al. (2008) conclude that EGUs are responsible for only $3.17 \mu \mathrm{g} / \mathrm{m}^{3}$ (see Tables 5-7). Therefore, the regional model appears to significantly underestimate the influence from the Boardman power plant. A likely source of this discrepancy is that our analysis utilized observations from the IMPROVE data collected at the Wishram site, whereas the conclusions of Pitchford et al. (2008) were based largely on a model simulation of air quality in the CRG. Figure 5-1 of Pitchford et al. (2008) compares the model simulation with observations from several sites in the CRG. For the November cases (right side of Fig. 5-1 in Pitchford et al., 2008), the model performs very poorly in reproducing the aerosol observations. For example, on the worst air quality days the observed aerosol scattering coefficient is up to $250 \mathrm{Mm}^{-1}$; however the model-predicted value is low by a factor of $\sim 3$. Pitchford et al. (2008) note, "None of the [model] configurations met all of the commonly accepted benchmarks for statistical performance, meaning that [the model] did not perform as well as it has historically performed in other air quality applications around the country."

In summary, our analysis of times when the Boardman power plant was temporarily shut down indicates a much larger influence from the power plant on air quality in the CRG compared to the Pitchford et al. (2008) study. We attribute this large discrepancy in results to the fact that the Pitchford et al. (2008) result is based on a regional air quality simulation, which performs poorly in reproducing the observed data and attempts to resolve atmospheric processes in complex terrain that are not resolved at this model resolution (Sharp and Mass 2004).

\section{Summary and implications}

We have analyzed 14 years of aerosol data spanning 1993-2006 from the IMPROVE site at Wishram $\left(45.66^{\circ} \mathrm{N}\right.$, $121.00^{\circ} \mathrm{W} ; 178 \mathrm{~m}$ a.s.l.) in the CRG (see Figs. 1 and 2). The highest $\mathrm{PM}_{2.5}$ days in the CRG occurred in autumn (Table 1) under easterly flow conditions (Fig. 3). Approximately 40\% of the 50 highest $\mathrm{PM}_{2.5}$ days have easterly flow. These days exhibited the highest $\mathrm{PM}_{2.5}$ mass concentrations compared to all other days. This result suggests that large industrial sources (namely the Boardman power plant, but also likely the Threemile Canyon dairy farm) on the east end of the CRG have a significant impact on haze in the CRG. Temporary shutdowns of the Boardman power plant allow us to estimate the impact from the power plant. Our analysis indicates a contribution from the plant to the annual average $\mathrm{PM}_{2.5}$ at the Wishram IMPROVE site of $0.87 \mu \mathrm{g} / \mathrm{m}^{3}$; a $3.94 \mu \mathrm{g} / \mathrm{m}^{3}$ contribution to mean November $\mathrm{PM}_{2.5}$ and a $7.40 \mu \mathrm{g} / \mathrm{m}^{3}$ contribution to November $\mathrm{PM}_{2.5}$ when the flow in the CRG is easterly (see Fig. 4 and Table 5).

We identify the Boardman power plant as a significant contributor to poor air quality in the CRG, in contrast to the Green et al. (2006) and Pitchford et al. (2008) studies, although $\mathrm{NH}_{3}$ emissions from the nearby dairy industry are likely a contributing factor. We believe the regional model employed in these other studies is a poor tool for such an analysis as it neither reproduces the observations well, nor does it have the resolution to capture atmospheric processes and transport in this region of complex terrain.

Acknowledgements. This study was supported by the Yakama Nation, Department of Natural Resources, Environmental Management Program. The authors are grateful for the support and encouragement from Rebecca Hawk, Aja DeCoteau and Phil Rigdon.

Edited by: B. N. Duncan 


\section{References}

Draxler, R. and Rolph, G. D.: HYSPLIT (HYbrid Single-Particle Lagrangian Integrated Trajectory) Model access via NOAA ARL READY web site, NOAA Air Resources Laboratory, Silver Spring, MD, 2002, available at: http://www.arl.noaa.gov/ready/ hysplit4.html, last access: May 2009.

Eatough, D. J., Richter, B. E., Eatough, N. L., and Hansen, L. D.: Sulfur chemistry in smelter and power-plant plumes in the western United States, Atmos. Environ., 15(10-1), 2241-2253, 1981.

Eldred, R. A., Ashbaugh, L. L., Cahill, T. A., Flocchini, R. G., and Pitchford, M. L.: Sulfate levels in the southwest during the 1980 copper smelter strike, J. Air Pollut. Cont. Assoc., 33(2), 110113, 1983.

Fenn, M. E., Geiser, L., Bachman, R., Blubaugh, T. J., and Bytnerowicz, A.: Atmospheric deposition inputs and effects on lichen chemistry and indicator species in the Columbia River Gorge, USA, Environ. Pollut., 146(1), 77-91, 2007.

Green, M., Xu, J., Adhikari, N., and Nikolich, G: Causes of Haze in the Gorge (CoHaGo), Final Report. Southwest Clean Air Agency, available at: http://www.swcleanair.org/gorgereports. html, released July 2006 .

Hewitt, C. N.: The atmospheric chemistry of sulphur and nitrogen in power station plumes, Atmos. Environ., 35(7), 1155-1170, 2001.
Malm, W. C., Schichtel, B. A., Ames, R. B., and Gebhart, K. A.: A 10-year spatial and temporal trend of sulfate across the United States, J. Geophys. Res., 107(D22), 4627, doi:10.1029/2002JD002107, 2002.

Malm, W. C., Sisler, J. F., Huffman, D., Eldred, R. A., and Cahill, T. A.: Spatial and seasonal trends in particle concentration and optical extinction in the United States, J. Geophys. Res., 99(D1), 1347-1370, 1994.

Pitchford, M. L, Green, M. C., Morris, R., Emery, C., Sakata, R., Swab, C., and Mairose, P. T.: Columbia River Gorge Air Quality Study, Final Science Summary Report, available at: http://www. swcleanair.org/gorgereports.html, released Feb 2008.

Romo-Kröger, C. M., Kiley, J. R., Dinator, M. I., and Llona, F.: Heavy metals in the atmosphere coming from a copper smelter in Chile, Atmos. Environ., 28, 705-711, 1994.

Seinfeld, J. H. and S. N. Pandis: Atmospheric Chemistry and Physics: From Air Pollution to Climate Change, 2nd Edn., Wiley-Interscience, Hoboken, New Jersey, 1232 pp., 2006.

Sharp, J. and Mass, C. F.: Columbia Gorge Gap Winds: Their Climatological Influence and Synoptic Evolution, Weather Forecast., 19(6), 970-992, 2004.

Vong, R. J., Moseholm, L., Covert, D. S., Sampson, P. D., O'Loughlin, J. F., Stevenson, M. N., Charlson, R. J., Zoller, W. H., and Larson, T. V.: Changes in rainwater acidity associated with closure of a copper smelter, J. Geophys. Res., 93(D6), 7169-7179, 1988. 